\title{
How important is the lesson of the correlation between advancing the globalization process and intensifying the money laundering phenomenon?
}

\author{
Akad AL-KASAWNIH \\ The Bucharest University of Economic Studies, Bucharest, Romania \\ akad.khasawneh@fm.gov.jo.
}

\begin{abstract}
It is true that advancing the globalization process generates a numerous negative externality. Such a negative effect is the proliferation of financial transactions carried out at or even beyond the limits of legality and fairness. The author of this study assumes that "the greater the cross-border financial flows, the greater the money-laundering operations and negative impact on the behavior of the economic actors". The truism related to this correlation must be deeply understood and the lessons to be delivered must be learned in time. Hidden economy is perceived as all incomes generated in legitimate way but not disclosed to tax administrations, as well as activities such as drug trafficking, gambling, smuggling and others. What distinguishes our study is Quantitative and analytical analysis and to draw conclusions based on those results, through the adoption of a digital index on economic globalization, and the adoption of another numerical indicator of money laundering with its components and weights as well. Additionally, a statistical analysis of the relationship between economic globalization and money laundering will be based on "Pearson correlation coefficient" as we are going to adopt one variable (Economic Globalization) as an independent variable and other variable (Money Laundering) as a dependent variable. The KOF index of globalization will be adopted here, and the selected countries as a study samples will be given a ranking from 1 to 15 according to their degree of economic globalization. Results of my research shows that a negative weak relationship correlation between the degree of the economic globalization of the state and the phenomenon of money laundering which is represented by the size of the hidden economy, which means that the increase of the value for the independent variable (economic globalization) leads to the decline of the value for the dependent variable (money laundering).
\end{abstract}

Keywords: Globalization; externality; money laundering; hidden economy; correlation coefficient.

\section{Introduction}

The study differs from other studies by the methodology it uses to link the relationship between the two variables by using the Quantitative and analytical analysis and to draw conclusions based on those results, through the adoption of a digital index on economic globalization (as an indicator for cross-border financial flows) with its components and weights, and the adoption of another numerical indicator for hidden economy (as an indicator for money laundering).

The KOF index of globalization will be adopted in this study as it covers most of the world countries (178 countries in 2018) ${ }^{1}$. Study samples were taken from various countries of the world. These countries have been divided into three groups (Group 1: Countries with high economic globalization; Group 2: Countries with a moderate economic globalization; Group 3: Countries with low economic globalization), each category of them includes five countries from different parts of the world. The selected

1 https://www.kof.ethz.ch/en/forecasts- -indicators/indicators/kof-globalisation-index.html.

(19.11.2018) 
countries will be given a ranking from 1 to 15 according to their degree of economic globalization.

On the other hand; the study will induce the volume of money laundering through the hidden economy or the shadow economy, The hidden economy is not only a group of criminal activities resulting from crimes such as drug trafficking or human trafficking only, but it is defined as all income-generating activities that are not recorded in the accounts of national output. Thus, the hidden economy gives indications of Money laundering activity in the country, there is a link between the phenomenon of money laundering and the phenomenon of the hidden economy, where money launderers use to trade in many activities away from the role of the state and gradually engage in legitimate activities to gain legitimacy for their activities and integrate into the formal economy ${ }^{2}$. The study refers to most recent studies that tried to induce the volume of money laundering through the hidden economy which is the study that has been done by Leandro Medina and Friedrich Schneider According to Leandro Medina and Friedrich Schneider's study published 2018 they have discussed methods available to estimate the shadow economy and presents new estimation results. The new results on the shadow economy are covering 158 countries all over the world and it were presented over 1991 to 2015. Therefore, the size of the hidden economy will be used to estimate the size of money laundering, which is derived from the average size of the estimated hidden economy in the countries from 2004 to 2015 according to the latest estimates of the hidden economy published in the (Leandro Medina and Friedrich Schneider) study which is published in $2018^{3}$.

Additionally, a statistical analysis of the relationship between economic globalization and hidden economy will be conducted based on "Pearson correlation coefficient" which is one of the most common methods for measuring the correlation coefficient between two variables, as we are going to adopt one variable (Economic Globalization) as an independent variable and other variable (Money Laundering) as a dependent variable. Pearson correlation coefficient will determine the relationship between two variables only and the correlation coefficient value is always between -1 and 1. For example: If the correlation coefficient value is positive, the correlation is positive, which means increasing the value of the independent variable will increases the value of the dependent variable. And if the correlation coefficient value is negative, the correlation is inverse, which means the increase in the value of the independent variable leads to the decline of the value of the second variable. Furthermore, the correlation is very strong when the value is close to 1 or -1 , and when the value approaches somehow from "zero" means a weak relationship or correlation. If the value is "zero" so there is none-correlation between the two variables at all.

\section{Literature Review}

The easy transfer of capital across the various countries has led to the growth of the organized crime movement and the increase in the circulation of funds of criminal organizations at the local and international levels. The phenomenon of money laundering is one of the biggest challenges facing financial and banking institutions and governmental and international bodies considering economic globalization. Money laundering is one of the most serious crimes of the digital economy era. It is the real

\footnotetext{
2 Friedrich Schneider, Andreas Buehn; Estimating the Size of the Shadow Economy: Methods, Problems and Open Questions, Discussion Paper No. 9820, March 2016, P 11.

${ }^{3}$ Leandro Medina and Friedrich Schneider, Shadow Economies Around the World: What Did We Learn Over the Last 20 Years?, January 2018.
} 
challenge for business and financial institutions. It is also an examination of the ability of legal rules to effectively combat criminal activities and combat their emerging patterns ${ }^{4}$. Due to the fact that advancing the globalization process generates a numerous negative externality, one of the main goals of this study is to discover if there is any connection between how much the countries are economically globalized and how much money laundering operations taking place within and inside them.

Money laundering is a way out of the criminals' dilemma of dealing with the outcomes of their crimes, especially those that generate large sums of money such as drug trafficking, arms smuggling, financial corruption, embezzlement and so on, so we can say that this crime represents the re-injection of the illegal revenue of organized crime into the formal economy through various mechanisms such as legitimate commercial and industrial enterprises to represent a legitimate facade that conceals illegal activities from the eyes of the members of anti-organized crime institutions ${ }^{5}$. This study will try to estimate the process of money laundering through what is called "hidden economy" which refers to all incomes generated in a legitimate way but not disclosed to tax administrations, as well as incomes generated by activities such as drug trafficking, gambling, smuggling and others.

The phenomenon of money laundering is considered one of the most serious phenomena and challenges faced by the economies of countries in general and financial and banking institutions in particular, This phenomenon has been increased by increasing the growth and effectiveness of international financial markets and multinational banks under the phenomenon of economic globalization which has facilitated the trans-border movement of capital becoming one of the most complex economic problems due to its contribution to maximizing the state of imbalance and instability, which are the cornerstone of achieving a society's prosperity and development ${ }^{6}$.

The study explores and focuses on economic and financial globalization and its measuring Indicators by KOF Globalization Index as its latest statistics of KOF indicator (2018) shows the ranking of 178 countries in the globalization index for the years from 1970 until 2015 on economic dimension (as it's the latest period that has been done by KOF institute so far and it covers 178 countries around the world).

As Lucian R.D argues in his study that money laundering operations benefited from globalization, the Internet and modern technology, as money launderers have developed their methods using these means and were able to reach the size of their crimes to 600 billion dollars, which is $2-5 \%$ of the gross national product of the world 7 , this study will tackle this phenomenon and attempts to measure the magnitude of the problem with an analysis of various countries (study sample), and for the first time a study attempts to measure the relationship between economic globalization (as an indicator for Cross-Borders Flows) and hidden economy (as an indicator for money laundering) by mathematical methods and statistical analysis to avail the relationship between these two variables by using "Pearson correlation coefficient".

\footnotetext{
${ }^{4}$ Borlini, Leonardo, Issues of the International Criminal Regulation of Money Laundering in the Context of Economic Globalization, "Paolo Baffi" Centre on Central Banking and Financial Regulation, University Bocconi, Milano - Italy, 2008.

5 Michael Blair Money Laundering Control in the Financial Regulations Context ،Volume 3 ،No. 2 ‘Journal of Money Laundering Control ‘(Autumn 1999) pp. 102-103.

${ }^{6}$ Miller, Rena S., Liana W. Rosen, James K. Jackson, “Trade-Based Money Laundering: Overview and Policy Issues" in Congressional Research Service, 2016.

${ }^{7}$ Lucian R.D, The Concept of Money Laundering in Global Economy, International Journal of Trade, Economic and Finance, Volume1, No 4, December, 2010.
} 
Referring to the all related studies, the theoretical aspect dominated these studies without resorting to quantitative methods of measurement, in addition they are addressing the subject from a legislative and legal point of view, whether international legislation or conventions or the domestic legislation of some countries. What distinguishes our study from these studies is Quantitative and analytical analysis and to draw conclusions based on those results.

\section{Methodology}

The study used the Quantitative and analytical analysis to draw statistical conclusions of the relationship between economic globalization and money laundering through "Pearson correlation coefficient", the measurement of economic globalization indicators in this study refers to KOF Globalization Index (as an independent variable) while the measurement of money laundering (as a dependent variable) will depend on the size of hidden economy as an only way for estimating the size of money laundering, which is derived from the average size of the estimated hidden economy in the countries from 2004 to 2015 according to the latest estimates of the hidden economy published in the (Leandro Medina and Friedrich Schneider) study which is published in 2018, then the study tried to measure the correlation coefficient between two variables through "Pearson correlation coefficient" that will determine the relationship between two variables which value is always between -1 and 1 .

Countries of study's sample have been divided into three groups according to KOF Globalization Index as its latest statistics of KOF indicator (2018); each of them includes five countries from different countries of the world. These groups will be as follow:

1-Countries with high economic globalization, which include (Singapore, Switzerland, Romania, Jordan, Nicaragua); and it is located within the Group of the most globalized countries on the KOF index (1-60).

2-Countries with a moderate economic globalization, which include (United States, Thailand, Saudi Arabia, Guatemala and Russian Federation); and it is located within the Group of the medium globalized countries on the KOF index (61 to 120).

3-Countries with low economic globalization, which include (Tunisia, Indonesia, Egypt, India and Bangladesh); and it is located within the group of the least globalized countries on the KOF index (121 to 178), table (1) shows the ranking of selected countries on the KOF scale of economic globalization only, which is adopted in this study.

On the other hand, the size of the hidden economy will be used to estimate the size of money laundering, which is derived from the average size of the estimated hidden economy in the countries from 2004 to 2015 as the latest estimates of the hidden economy published in the (Leandro Medina and Friedrich Schneider) study which is published in 2018. The new results on the shadow/hidden economy are covering 158 countries all over the world and it were presented over 1991 to 2015. Table (2) shows the size of the hidden economy of the countries of study's samples over the period 1991 to 2015 - Part II (2004-2015).

After that the study tried to statically analyze relationship between the degree of economic globalization and the money laundering according to the rank of selected countries as a study sample through "Pearson correlation coefficient". This study adopts economic globalization variable as an independent variable and money laundering variable as a dependent variable. Pearson Correlation Coefficient will determine the relationship between two variables only where the correlation coefficient 
value is always between -1 and 1 . For example: If the correlation coefficient value is positive, the correlation is positive, which means increasing the value of the independent variable will increases the value of the dependent variable. And if the correlation coefficient value is negative, the correlation is inverse, which means the increase of the value for the independent variable leads to the decline of the value for the dependent variable. Furthermore, the correlation is very strong when the value is close to 1 or -1 , and when the value approaches somehow to "zero" that means a weak relationship or correlation between the variables, and if the value is "zero" so there is no correlation between the two variables at all.

The analysis methodology will be as follows:

1. Economic globalization (independent variable):

The KOF index of globalization will be adopted here, and the selected countries as a study samples will be given a ranking from 1 to 15 according to their degree of economic globalization. The most globalized country (Singapore) is 15 while the least globalized (Bangladesh) is 1.

The following table shows the ranking of the selected countries according to the KOF scale of overall economic globalization ${ }^{8}$ :

\begin{tabular}{|c|c|c|}
\hline Country & $\begin{array}{c}\text { Overall Economic } \\
\text { Globalization }\end{array}$ & Ranking \\
\hline Singapore & 92.47 & 15 \\
\hline Switzerland & 83.82 & 14 \\
\hline Romania & 71.68 & 13 \\
\hline Jordan & 68.15 & 12 \\
\hline Nicaragua & 64.74 & 11 \\
\hline United States & 63.83 & 10 \\
\hline Thailand & 59.89 & 9 \\
\hline Guatemala & 54.76 & 7 \\
\hline Saudi Arabia & 53.03 & 6 \\
\hline Russian Federation & 50.95 & 5 \\
\hline Tunisia & 46.08 & 4 \\
\hline Indonesia & 44.23 & 2 \\
\hline Egypt & 34.50 & 1 \\
\hline India & 29.78 & \\
\hline Bangladesh & 20.95 & 3 \\
\hline & & \\
\hline & & \\
\hline
\end{tabular}

2. Money laundering (dependent variable):

The size of the hidden economy will be adopted here, "hidden economy" means all revenue-generating activities that not recorded in GDP; Either to hide it or to evade the legal obligations associated with the disclosure of such activities, or because the nature of such activities are against the legal system in the country. According to this definition, the activities of the hidden economy include all incomes generated in legitimate way but not disclosed to tax administrations, as well as traditional criminal activities such as drug trafficking, gambling, smuggling and others. The selected countries as a study samples will be given a ranking from 1 to 15 according to the

\footnotetext{
${ }^{8}$ The table was prepared by the researcher based on the values and order of economic globalization for the countries of study samples according to the KOF index of economic globalization.
} 
average size of the hidden economy between 2004 and 2015. The largest size of the hidden economy within the study sample goes for (Guatemala) that will be given 15 and the lowest size for (United States) that will be number 1.

The following table shows the ranking of the selected countries according to the average size of the hidden economy between 2004 and 20159:

\begin{tabular}{|c|c|c|}
\hline Country & $\begin{array}{c}\text { Average Size of the } \\
\text { Hidden Economy }\end{array}$ & Ranking \\
\hline Guatemala & 54.74 & 15 \\
\hline Thailand & 50.63 & 14 \\
\hline Nicaragua & 42.63 & 13 \\
\hline Switzerland & 40.04 & 11 \\
\hline Russian Federation & 38.42 & 10 \\
\hline Tunisia & 35.31 & 9 \\
\hline Egypt & 34.24 & 8 \\
\hline Bangladesh & 33.24 & 7 \\
\hline Romania & 30.14 & 5 \\
\hline Indonesia & 24.11 & 4 \\
\hline India & 23.91 & 3 \\
\hline Jordan & 17.38 & 2 \\
\hline Saudi Arabia & 16.65 & 1 \\
\hline United States & 11.90 & 6 \\
\hline
\end{tabular}

3. In order to obtain more accurate results, a number of sub-indices in the actual economic flows of the economic globalization index (de facto) will be taken as an independent variable to study the relationship between economic globalization and money laundering. Table (3) shows the ranking of the sample countries based on these sub-indicators, which include: trade globalization (trade in goods, trade in services, trade partner diversification), and financial globalization (foreign direct investment, portfolio investment, international debt, international income payments) all of them in relation to the percentage of GDP, and then the overall economic globalization index will be used as an independent variable to interpret the relationship as a whole.

4. The dependent variable of the size of the hidden economy in this study will follow the change in each of the sub-indices in the actual economic flows of economic globalization. To measure this, the above scores will be analyzed according to the "Pearson Correlation Coefficient" to produce results showing the correlation between the two variables.

\section{Results and Conclusion}

After performing the statistical analysis according to the above data, the study finds "Pearson Correlation Coefficient' value as follows:

\footnotetext{
${ }^{9}$ The table was prepared by the researcher based on the average percentage of the hidden economy of the countries of the study sample published in the Leandro Medina and Friedrich Schneider study, and the average GDP based on the data from the International Monetary Fund (IMF).
} 
The relationship between the ratio of international trade to GDP and the hidden economy that represents the volume of money laundering: Pearson Correlation Coefficient was $(0.0152+)$, which means that there is a positive weak relationship correlation between the ratio of international trade to the gross national product of the state and money laundering phenomenon represented by the size of the hidden economy.

The correlation between the ratio of foreign direct investment to gross domestic product (GDP) and the hidden economy, which represents the volume of money laundering: Pearson Correlation Coefficient was $(0.4989+)$, which means that there is a positive medium relationship correlation between the ratio of foreign direct investment to the gross domestic product (GDP) of the state and the phenomenon of money laundering which represent the size of hidden economy.

The relationship between the ratio of portfolio investment to GDP and the hidden economy, which represents the volume of money laundering: Pearson Correlation Coefficient was (0.3751-), which means that there is a negative weak relationship correlation between the ratio of portfolio investment to the gross domestic product and the phenomenon of money laundering which represent the size of hidden economy.

The relationship between the overall economic globalization and the average size of the hidden economy, which represents the volume of money laundering: After the statistical analysis according to the data referred to above, Correlation Coefficient Pearson has reached (0.1533-), which means that there is a negative weak relationship correlation between the degree of the economic globalization of the state and the phenomenon of money laundering which is represented by the size of the hidden economy.

One of the hypotheses of this study is that there is a causal relationship between economic globalization (independent variable) and money laundering operations (dependent variable), and the direction of this relationship is a positive relationship, as we noticed earlier there is a positive weak relationship between the sub-indices of economic globalization and money laundering when we take some of the indices (international trade $0.0152+$, foreign direct investment $0.4989+$ ). On the other hand; there is a negative weak relationship when it is applied on other indices (portfolio investment to GDP 0.3751-).

As a result, this study took the overall index of economic globalization and the total average size of the hidden economy to be adopted for measuring the final relationship between these two variables by using the Pearson Correlation Coefficient which represent the value of (0.1533-), which means that there is a negative weak relationship correlation between the degree of the economic globalization of the state and the phenomenon of money laundering which is represented by the size of the hidden economy.

One of the hypotheses of this study is that there is a causal relationship between economic globalization (independent variable) and money laundering operations (the dependent variable), and the direction of this relationship is a positive, while the result of these study shows the opposite (a negative weak relationship correlation between the degree of the economic globalization of the state and the phenomenon of money laundering which is represented by the size of the hidden economy) which means that the increase of the value for the independent variable (economic globalization) leads to the decline of the value for the dependent variable (money laundering). The negative correlation coefficient value can be explained to more than one reason due to the following: 
1. The effectiveness of the international efforts to combat money laundering, whether by the country itself or in cooperation under the umbrella of many international institutions and bodies that deal with combating financial and economic crimes, mainly money laundering, as these efforts are more effective in developed industrial countries.

2. The difficulty of having accurate measurement for the volume of money laundering in the countries of the world, as all international institutions concerned with the fight against money laundering refrain from providing estimates on the real size of this phenomenon and only provides estimations. Therefore, this is replaced by the measurement of indicators of the size of money laundering as this study accomplished where the volume of the hidden economy was used.

3. The phenomenon of money laundering is linked to the origins of these funds, which have their own dimensions (economic, social, political and geographic ones). Therefore, the effects cannot be limited to economic and financial forms of globalization only.

4. Results of this study shows that a negative weak relationship correlation between the degree of the economic globalization of the state that represent crossborder financial flows and the phenomenon of money laundering that represent the volume of hidden economy, which means that the increase of the value for the independent variable (economic globalization) leads to the decline of the value for the dependent variable (money laundering).

\section{Table (1) Sorting the selected countries as a sample of the study according to the KOF scale of economic globalization ${ }^{10}$ :}

\begin{tabular}{|c|c|c|c|}
\hline Economic globalization & Country & 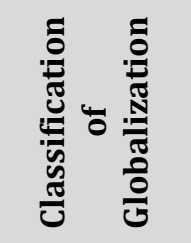 & $\dot{z}$ \\
\hline 92.47 & Singapore & \multirow{5}{*}{ 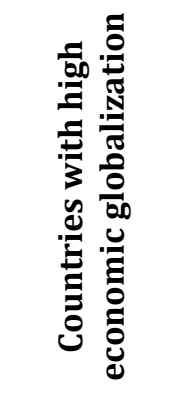 } & 1 \\
\hline 83.82 & Switzerland & & 2 \\
\hline 71.68 & Romania & & 3 \\
\hline 68.15 & Jordan & & 4 \\
\hline 64.74 & Nicaragua & & 5 \\
\hline 63.83 & $\begin{array}{l}\text { United } \\
\text { States }\end{array}$ & \multirow{4}{*}{ 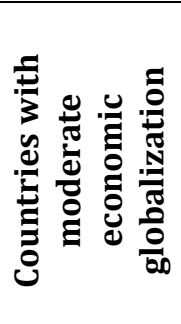 } & 6 \\
\hline 59.89 & Thailand & & 7 \\
\hline 54.76 & Guatemala & & 8 \\
\hline 53.03 & Saudi Arabia & & 9 \\
\hline
\end{tabular}

\footnotetext{
${ }^{10}$ The table was prepared by the researcher based on the values and order of economic globalization for the countries of study samples according to the KOF index of economic globalization.
} 


\begin{tabular}{|c|c|c|c|}
\hline 50.95 & $\begin{array}{c}\text { Russian } \\
\text { Federation }\end{array}$ & & 10 \\
\hline 46.08 & Tunisia & \multirow{5}{*}{ 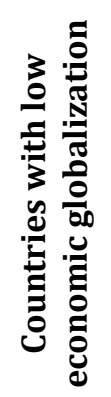 } & 11 \\
\hline 44.23 & Indonesia & & 12 \\
\hline 34.50 & Egypt & & 13 \\
\hline 29.78 & India & & 14 \\
\hline 20.95 & Bangladesh & & 15 \\
\hline
\end{tabular}

PICBE |

Table (2) Size of the hidden economy of the countries of study samples over the period 1991 to 2015 - Part II (2004-2015): 11

\begin{tabular}{|c|c|c|}
\hline Rank & Country & The Average Size of the Hidden Economy 2004- \\
& & 2015 \\
\hline 1 & Singapore & 11.90 \\
\hline 2 & Switzerland & 40.04 \\
\hline 3 & Romania & 30.14 \\
\hline 4 & Jordan & 17.38 \\
\hline 5 & Nicaragua & 42.63 \\
\hline 6 & United States & 8.34 \\
\hline 7 & Thailand & 50.63 \\
\hline 8 & Saudi Arabia & 16.65 \\
\hline 9 & Guatemala & 54.74 \\
\hline 10 & Russian Federation & 38.42 \\
\hline 11 & Tunisia & 35.31 \\
\hline 12 & Indonesia & 24.11 \\
\hline 13 & Egypt & 34.24 \\
\hline 14 & India & 23.91 \\
\hline 15 & Bangladesh & 33.59 \\
\hline
\end{tabular}

Table (3) The ranking of the selected Countries according to overall economic globalization and its sub-indicators ${ }^{12}$ :

\begin{tabular}{|c|c|c|c|c|c|c|c|c|c|c|}
\hline \multirow{2}{*}{$\begin{array}{c}\text { Country } \\
\text { Guatemala }\end{array}$} & \multicolumn{2}{|c|}{$\begin{array}{l}\text { International } \\
\text { Trade in Goods } \\
\text { and Services* }\end{array}$} & \multicolumn{2}{|c|}{$\begin{array}{l}\text { Foreign Direct } \\
\text { Investment }^{* *}\end{array}$} & \multicolumn{2}{|c|}{$\begin{array}{c}\text { portfolio } \\
\text { investment*** }\end{array}$} & \multicolumn{2}{|c|}{$\begin{array}{c}\text { Overall Economic } \\
\text { Globalization }\end{array}$} & \multicolumn{2}{|c|}{$\begin{array}{c}\text { Average Size } \\
\text { of the Hidden } \\
\text { Economy }\end{array}$} \\
\hline & 6.3 & 1 & 980.62 & 5 & 447.90 & 3 & 54.76 & 8 & 54.74 & 15 \\
\hline Thailand & 11.3 & 6 & $116,526.94$ & 10 & $53,422.80$ & 10 & 59.89 & 9 & 50.63 & 14 \\
\hline Nicaragua & 15.9 & 11 & 640.60 & 3 & 203.60 & 2 & 64.74 & 11 & 42.63 & 13 \\
\hline Switzerland & 7.5 & 4 & $1,700,827.09$ & 14 & $1,410,330.66$ & 14 & 83.82 & 14 & 40.04 & 12 \\
\hline $\begin{array}{c}\text { Russian } \\
\text { Federation }\end{array}$ & 12.1 & 7 & $468,567.46$ & 12 & $73,945.51$ & 11 & 50.95 & 6 & 38.42 & 11 \\
\hline Tunisia & 16 & 12 & 502.36 & 1 & 50.72 & 1 & 46.08 & 5 & 35.31 & 10 \\
\hline
\end{tabular}

${ }^{11}$ The table was prepared by the researcher based on the average percentage of the hidden economy of the countries of the study sample published in the Leandro Medina and Friedrich Schneider study, and the average GDP based on the data from the International Monetary Fund (IMF).

12 The table was prepared by the researcher according to overall economic globalization and its sub-indicators 


\begin{tabular}{|c|c|c|c|c|c|c|c|c|c|c|}
\hline Egypt & 15.7 & 10 & $7,426.00$ & 6 & $1,556.50$ & 5 & 34.50 & 3 & 34.24 & 9 \\
\hline Bangladesh & 25.2 & 15 & 797.06 & 4 & $3,193.96$ & 7 & 20.95 & 1 & 33.24 & 8 \\
\hline Romania & 17 & 13 & $8,055.76$ & 7 & $4,528.33$ & 8 & 71.68 & 13 & 30.14 & 7 \\
\hline Indonesia & 12.5 & 8 & $77,189.89$ & 8 & $17,315.66$ & 9 & 44.23 & 4 & 24.11 & 6 \\
\hline India & 21.9 & 14 & $155,175.73$ & 11 & $2,565.33$ & 6 & 29.78 & 2 & 23.91 & 5 \\
\hline Jordan & 6.5 & 2 & 619.01 & 2 & 666.06 & 4 & 68.15 & 12 & 17.38 & 4 \\
\hline Saudi Arabia & 10.9 & 5 & $79,069.55$ & 9 & $156,976.41$ & 12 & 53.03 & 7 & 16.65 & 3 \\
\hline Singapore & 13.3 & 9 & $841,402.36$ & 13 & $1,248,931.02$ & 13 & 92.47 & 15 & 11.90 & 2 \\
\hline United States & 7.2 & 3 & $8,909,995.00$ & 15 & $12,543,844.00$ & 15 & 63.83 & 10 & 8.34 & 1 \\
\hline
\end{tabular}

1276

*: World Bank WDI 2017. (http://wdi.worldbank.org/table/4.9)/ (Sum of average annual growth for exports and imports in goods and services as share of GDP).

**: International Monitory Funds (IMF) 2017. (http://data.imf.org/regular.aspx?key=61468209)

***: International Monitory Funds (IMF) 2017. (http://data.imf.org/regular.aspx?key=61468209)

\section{References:}

Borlini, Leonardo, Issues of the International Criminal Regulation of Money Laundering in the Context of Economic Globalization, "Paolo Baffi" Centre on Central Banking and Financial Regulation, University Bocconi, Milano - Italy, 2008.

Friedrich Schneider, Andreas Buehn; Estimating the Size of the Shadow Economy: Methods, Problems and Open Questions, Discussion Paper No. 9820, March 2016, P 11.

Leandro Medina and Friedrich Schneider, Shadow Economies Around the World: What Did We Learn Over the Last 20 Years?, January 2018.

Michael Blair Money Laundering Control in the Financial Regulations Context ،Volume 3 ،No. 2 ،Journal of Money Laundering Control ‘(Autumn 1999) pp. 102-103.

Miller, Rena S., Liana W. Rosen, James K. Jackson, "Trade-Based Money Laundering: Overview and Policy Issues" in Congressional Research Service, 2016.

Lucian R.D, The Concept of Money Laundering in Global Economy, International Journal of Trade, Economic and Finance, Volume1, No 4, December, 2010.

https://www.kof.ethz.ch/en/forecasts-indicators/indicators/kof-globalisationindex.html. (19.11.2018) 